p. 224), in what a marvellous manner the development of the hypophysis cerebri of Vertebrates, with its oral and neural portions, accords with the development of the permanent œsophagus and its special nervous system in Annelids. I now submit some no less striking resemblances between the two groups; and I am of opinion that we may hope, with work and increasing knowledge, to encounter many more such, as yet undreamt of.

Anatomisches Institut, Freiburg i/B., September 2 I. J. BEARD.

\section{THE JOURNAL OF THE ROYAL} AGRICULTURAL SOCIETY.'

$I^{\mathrm{T}}$ is seldom that the Journal of an important Society so abounds with obituary notices of prominent contributors as the one now before us. The sad refrain of "In Memoriam" runs through but too many of the closing pages of the number, in affectionate remembrance of names which have been associated with the advancement of agricultural knowledge throughout a considerable part of this century. The late Charles Randell, of Chadbury, was essentially a farmer of the widest views and experience, and full of sympathy for scientific work. The late John Chalmers Morton, the late John Algernon Clarke, and the late John Coleman ranked among the most distinguished ornaments of the literary aspect of agriculture. The editor, remarking upon these losses, says : "It is a noteworthy but melancholy circumstance that, in the short space of six months, the three leading professional writers on agricultural subjects should have been gathered in by the Great Harvester." We should be wanting in respect to pass over unnoticed these bereavements, and when we call to mind the very recent deaths of Dr. Voelcker and Mr. H. M. Jenkins, the late secretary and editor, we must admit that this Society has sustained exceptionally heavy losses.

The present number, however, bears witness to the fact that able successors are to be found to carry on the good work of the Society, and that, as the veterans pass away, young and enthusiastic labourers step into their places.

As usual, the material of the half-yearly issue may be divided into official Reports and articles by unattached contributors. The first section includes the Reports on the farm prize competition in Northumberland; on the implements, live stock, and poultry at the Nottingham meeting of last summer ; on horse-shoeing, followed by an able paper on the structure of the horse's foot by Prof. G. T. Brown, C.B.; and on the Newcastle (I887) engine trials, by the Consulting Engineer to the Society. These Reports we cannot do more than notice as well worth the attention both of mature agriculturists and students of the art. The remaining portion of the volume contains articles upon the principles of forestry, farming in the Channel Islands, the propagation and prevention of smut in oats and barley, and various papers on stock-feeding and crop-growing.

None of these papers will create more interest than that upon the herbage of old grass-land, by Dr. W. Fream, and this paper stands prominently forward as the only one which may be described as an original investigation. The question is not only important, but controversial. The best way of producing that inimitable natural product, a rich pasture, has long been a subject of vital interest to landowners. In the long period of agricultural depression, grass-lands have scarcely shiared in the general depreciation of values. Good grass-land will always let, and it is likely to maintain its value. The difficulty of converting tillage land into grass has always, however, been a problem hard of solution, and anyone who throws light upon this question is deserving of gratitude.

One of the chief difficulties has consisted in ascertaining the proper descriptions of seeds for producing a permanent pasture, and a great deal of discussion has taken place upon the relative merits and dernerits of the members of the large family of the Graminea, as well as of the Leguminose, compo-ing the complex herbage of a good meadow or pasture. Certain grasses have been named as especially suitable, while others, although occurring in all pastures, have been condemned as worse than useless. On the other hand, it has been freely asserted that many of our best grazing-lands are largely composed of grasses which have been stigmatized as worthless by certain authorities, and the inspection of high-class pastures has often staggered the botanist by the perverseness with which which they carried the " wrong" descriptions of grasses, and nevertheless held their own as producers of valued hay, or, if grazed, of beef, mutton, and milk.

Second Series, vol. xxiv. Part I. (London: John Murray, 1888.)
One of the most maligned of the grasses of late years has been common rye-grass. This grass, although popular with farmers, was stigmatized by Mr. Faunce de Laune, in an able paper published a few years ago, as a short-lived and inferior grass, foisted upon the farmers by seedsmen because of its cheapness and the ease with which it germinated and covered the ground. Mr. Faunce de Laune ruined rye-grass, his views being some. what too precipitately indorsed by the officers of the Royal Agricultural Society, and the seed trade was ruled into unwilling obedience. Rye-grass was banished from all mixtures sown by truly enterprising and advanced agriculturists, but its use still lingered among the less scientific but more practical members of the confraternity of farmers.

In spite of this crusade against rye-grass, many observing and scientific agriculturists were in doubt, especially as rye-grass was seen to occupy a leading position in all natural pastures, and hence its evanescent or short-lived character was doubted.

Prof. Fream, partly from a desire to test the true value of ryegrass, but also with a view to investigating the botanical composition of good grass-land, put himself in communication with a number of experienced agriculturists in England and Ireland, and with their co-operation transplanted twenty-five representative sods, 2 feet long, I foot broad, and 9 inches deep, from as many pastures, and planted them side by side in a bed 72 feet long and 6 feet wide in the Botanical Garden of the College of Agriculture, Downton. This transplantation was accomplished in the winter and spring of $1887-88$.

In the month of July the herbage of each turf was cut, and submitted to a quantitative botanical examination, with very interesting and surprising results. In the first place, these samples of pastures, brought from twelve English and eight Irish counties, gave evidence that the preponderance of their herbage was composed of two plants, one being the maligned and tabooed perennial rye-grass (Lolium perenne), and the other chief constituent being common white clover (Trifolium repens). As each of the twenty-five sods was selected from the best grass-land of its district by resident agriculturists of wellknown judgment, the case appears to be conclusive in favour of the recently, but only recently, discarded grass. The actual fact is that rye-grass constituted in the various plots high percentages of the total gramineous herbage, as the following figures show :-No. I turf (Wainfleet), 75 per cent.; No. 2 turf (Tenterden), 90 per cent. ; No. 3 turf (Sherborne), 76 per cent. ; No. 4 turf (Sherborne), 77 per cent.; No. 5 turf (Somerset), 82 per cent. ; No. 6 turf (Derbyshire), is per cent. ; No. 7 turf (Somerset), 90 per cent. ; No. 8 turf (Tipperary), 66 per cent. ; No. Io turf, 78 per cent. ; No. ir turf, 83 per cent.; No. I 2 turf, 90 per cent. It is needless to continue this list, and it is sufficient to say that, with very trifling exceptions, these important turfs unanimously showed themselves in favour of rye-grass; in fact, this species heads the list in 21 out of the 25 cases.

Similarly, the leguminous herbage was found to contain one constituent in paramount abundance-namely, white clover so that it may be approximately stated that, while the grassy herbage was chiefly composed of rye-grass, the leguminous herbage was chiefly composed of white Dutch clover. In one case-that of a turf sent by Sir Louis T. Delcomyn, of the Old Court, Bradwardine, Herefordshire-rye-grass and white clover composed the entire herbage, without the intervention of another plant of any kind whatsoever.

A more crushing piece of evidence against the enemies of perennial rye-grass could not well have been produced, and the farmer will once more be justified for his slowness in accepting the dicta of some of his would-be teachers. The case is of such practical importance that we have dealt with it at some length ; and it should be added that the percentage botanical composition of the gramineous herbage of each turf is given in detail, so that the labour involved must have been very great.

Prof. Curtis, in a useful paper upon Forestry, deprecates the founding of a School of Forestry, but recommends the formation of a representative Board of Examiners in Forestry on the lines proposed by Mr. Rogers, of the Surveyors' Institution, and Colonel Pearson, to the Select Committee on Forestry. The Report on the Farm Prize Competition is of value for comparative purposes, chiefly as showing the amounts expended by good farmers upon fertilizers and feeding-stuffs, and the different practices obtaining in the locality where the competition took place. The remaining papers we cannot at present notice particularly, but have indicated their presence. 